\title{
The Role of Extracted Carotenoid from Staphylococci as Antioxidant and Antibacterial
}

\author{
* Sarab D. Alshamaa \\ Muna M. Issam \\ Department of Biology/College of Science/ University of Mosul \\ *E-mail: drsarabalshamaa@yahoo.com
}

(Received 17/9/2013; Accepted 25/11/2013)

\begin{abstract}
The ability of some Staphylococci isolates producing and non-producing carotenoid pigments to resist the different concentrations of $\mathrm{H}_{2} \mathrm{O}_{2}$ and Staphylococcus aureus ranged between $0.6-1.5 \%$ studied in dark and light had been studied. The results showed that staphyloxanthin producing strains were more resistant than carotenoid producing pigmented and non-pigmented strains and this resistance was better in dark than light due to the pigment oxidation. Extraction and partial purification of the pigment was done and some biochemical properties such as conductivity and UV-spectra were performed. High conductivity had been registered at 469.25, 391.25 ms besides UV-spectra determination revealed peaks at 450-468 nm for staphyloxanthin and orangecarotenoid pigments respectively. Antibacterial ability of partially purified pigments had been tested against different bacterial isolates, results indicated that partially purified staphyloxanthin had highest antibacterial activity against Staphylococcus epidermidis, Acinetobacter baumanii and Proteus mirabilis, the lowest activity appeared against both Psedumonas aeruginosa and Shigella dysenteri, the other carotenoid pigment on the other hand, had no antibacterial effects against these isolates.
\end{abstract}

Keywords: Staphyloxanthin, carotenoid pigment, Staphylococcus, antioxidant

\section{دور الكاروتينوبد المستخلص من الهقويلت كمضاد للكسة والجراثيم}

\section{الملغص}

درس في هذا البهث قابلية بعض عزلات بكتريا العقوديت المتتجة للصبغلت الكاروتينية وغير المنتجة لها على مقاومة ترلكيز مختلفة لبيروكسيد الهيدروجن تراومت بين 0.5\%-6.6\% في الضوء والظالام وتبين بأن العزلات المنتجة

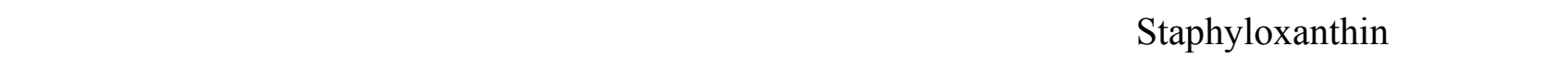

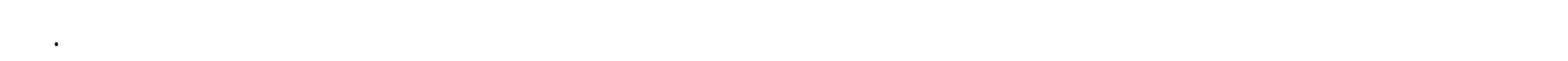
لستخلاص وتقية هذه الصبغلت تقية جزئية ودبست بعض الصفلت الكيموحيوية لهاتين الصيغتين مل التوصيلية الكهربائية electrical conductivity توصيلية عالية بلغت 469.25 ، 390.25 مليسيمينز وحزم المتصاص عند الأطول الموجية 466 و478 نانوميترللمأشعة فوق البفنجية للكل من صبغتي الـ ـ _ Staphyloxanthin والصبغة البرتقالية على التوالي، كما لختبرت قابلية هالتين الصيغتين

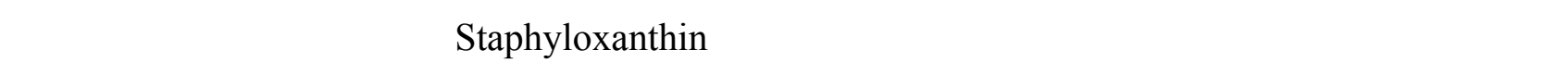

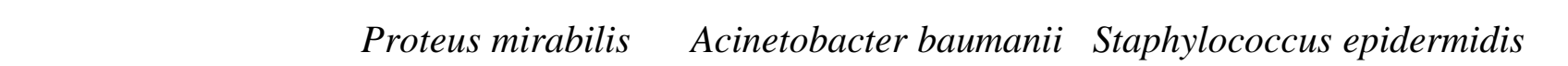
و Shigella dysenteri Psedumonas aeruginosa 


\section{INTRODUCTION}

Staphyloxanthin (STX) is an orange-red Triterpenoid, membrane-bond carotenoid which plays a role in the environmental fitness of Staphylococcus aureus (Clauditz et al., 2006) besides it provides integrity to its cell membrane $(\mathrm{CM})$ and limits oxidative host defense mechanism (Mishra et al., 2011). Staphyloxanthin consists of a c30 polyene carbon back -bone with alternating single and double bonds typical of carotenoid pigments, these alternating bonds are able to absorb excess energy from reactive oxygen species ROS(El-Agamey et al., 2004).

Most Staphylococcus aureus produce the orange carotenoid staphyloxanthin in which biosynthetic genes are organized in an operon, crtOPQMN, with a $\sigma^{\mathrm{B}-}$ dependent promoter up stream of crtO and atermination region downstream of $c r t N$. The first step in staphyloxanthin biosynthesis is the head-to head. Condensation of two molecules of farnesyl diphosphate to form dehydrosqualene (4-4-diapophytoene). Catalyzed by the dehydrosqualenesynthase CrtM (Pelz et al., 2005).

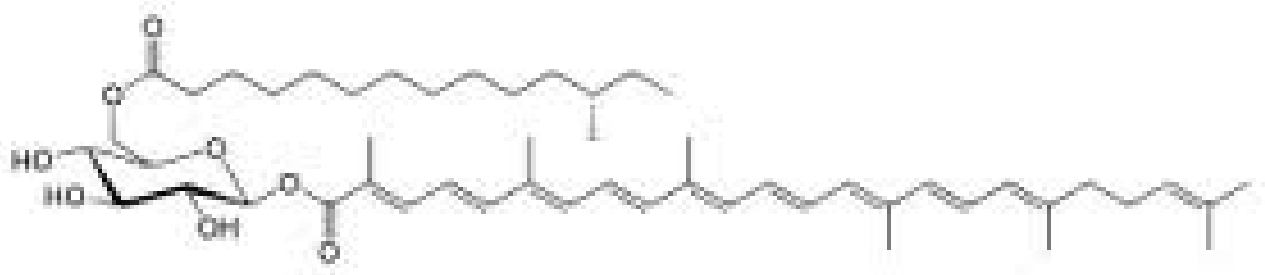

Fig. 1: Chemical structure of staphyloxanthin (Liu et al., 2008)

One important mechanism by which phagocytic cells eliminate pathogens is through the release of reactive oxygen species generated by nicotinamide adenin dinucleatide phosphate (NADPH) oxidase (Fang, 2004). It has been suggested that bacterial carotenoids such as these expressed by Staphylococcus aureus and Staphylococcus capitis could serve as protective function against these defense molecules (Liu et al., 2005). The research aimed to extract and partially purify carotenoid pigments and reveal its role as an antioxidant factor, study its chemical and physical properties, the antibacterial effect of staphyloxanthin with imipemen a broad spectrum antibiotic against the selected bacterial isolates.

\section{MATERIAL AND METHODS}

Bacterial isolates: Golden and non-golden Staphylococcus aureus isolates were obtained from ALZahrawii teaching hospital, laboratory definitive identification was done by using biochemical tests after Gram staining had been performed first. Bacterial isolates were cultured on a selective media (mannitol salt agar with $7-9 \% \mathrm{NaCl}$ ) which allow Staphylococcus aureus to produce yellow colored colonies, as a result of mannitol fermentation. Biochemical tests such as catalase, coagulase, Dnase for final differentiation of Staphylococcus aureus (Ryan, Ray, 2004). Staphylococcus capitis strain and other selected bacterial strains (mentioned later) were obtained from Bacterial Strains Bank, Department of Biology/ College of Science/Mosul university.

Growth condition and pigment extraction: Staphyloxanthin was isolated from golden Staphylococcus aureus, while other carotenoids pigments were isolated from orange Staphylococcus capitis. Bacterial strains were grown on tryptic soy agar (TSA) plates $\mathrm{pH} 7.2 \pm 0.2$ adjusted by $\mathrm{pH}$ meter (OAKTON/SINGEPORE), these plates were inoculated by streaking method three independent parallel plating were prepared. After incubation at $37 \mathrm{C}^{\circ}$ for $24 \mathrm{~h}$.Cells were scraped from the ( TSA) plate placed in test tube containing $3 \mathrm{ml}$ of methanol and incubated at $50 \mathrm{C}^{\circ}$ for $5 \mathrm{~min}$ in water bath then the extracted pigment was centrifugated (REMI/INDIA) at 3000 rpm for $10 \mathrm{~min}$. This process was repeated twice until no further pigment was extracted (Schmidt et al., 1994). All manipulations during preparations of the pigments were carried out rapidly and the effects of light were avoided by carrying out the extractions in glass covered, with aluminum foil. After centrifugation the supernatant containing the pigment was concentrated to small volumes in vacuo (BINDER/USA) and then extracted with ethyl acetate (Plez et al., 2005). 
Partial purification of staphyloxanthin and other pigments: The extracted pigments were subjected to silica gel $60(1.5,4.0 \mu \mathrm{m})$ Colum chromatography. The colored fraction was eluted with ethyl acetate, and the individual fractions were evaporated to dryness (Plez et al., 2005).

Oxidant suscepility assay: Three sets of duplicate cultured plates with $10^{8}$ cells of pigmented and non-pigmented Staphylococcus aureus strains as well as Staphylococcus capitis were incubated for $1 \mathrm{~h}$ in dark wrapped in foil in the presence of various concentration of discs $\mathrm{H}_{2} \mathrm{O}_{2}$ ranging from $0.6-1.5 \%$, after incubation at $37 \mathrm{C}^{\circ}$ for $24 \mathrm{~h}$, the effect was assessed by growth inhibition zones . Control plates situated exactly $10 \mathrm{~cm}$ from $100 \mathrm{w}$ light source to determine the evidence of bacterial killing (Liu et al., 2005).

Spectral measurements: Spectra of extracted pigments were recorded from 190.0 to $1100.0 \mathrm{~nm}$ with a $2 \mathrm{~nm}$ sampling interval using 1601uv-visible spectrophotometer (UV1650PC/SHIMADZU/JAPAN) Chemistry Department/ College of Science /Mosul University).

Conductivity measurements: The Conductivity of the extracted pigments were measured by using conductivity instrument (HANA/EUROPE).

Antibacterial activity of staphyloxanthin: Antibacterial susceptibility testing of staphyloxanthin pigment and antibiotic imipemen $(10 \mathrm{mcg})$ were carried out by Kirby-Bauer's disc diffusion techniques, against the selected bacterial isolates: Acinetobacter baumanii, Escherichia coli, Proteus mirabilis, klebsiella penumoniae, Shigella dysenteri, Salmonella enteritis, Psedomonas aeruginosa, Bacillus subtilis and Staphyloccus epidermidis. The extracted carotenoid pigments were dissolved in DMSO and used for bioassay against these bacteria. Sterile discs $6 \mathrm{~mm}$ diameter were impregnated with $400 \mathrm{mg} / \mathrm{ml}$ extracts and introduced into the nutrient agar medium inoculated with the tested selected bacterial strains. The plates were incubated at $37^{\circ} \mathrm{C}$ for 24 hours. Antimicrobial activity was evaluated by measuring the zone of inhibition (Chung et al., 2011).

\section{RESULTS AND DISCUSSION}

Pigmented and non -pigmented Staphylococcus aureus as well as the isolate of Staphylococcus capitis that produce orange carotenoid pigment other than staphyloxanthin had been identified and utilized.

Fig. (2) revealed the morphological characteristic of these isolates. Yellowish golden staphyloxanthin producing strain, Staphylococcus aureus and orange carotenoid producing strain Staphylococcus capitis as well as non-pigmented strain Staphylococcus aureus incubation of these strains with different concentration of $\mathrm{H}_{2} \mathrm{O}_{2}$ saturated discs had been accomplished as shown in Fig (3-5) that indicate the decreased viability of Staphylococcus aureus and Staphylococcus capitis with increasing $\mathrm{H}_{2} \mathrm{O}_{2}$ concentration to different extent. The viability of Staphylococcus aureus producing staphyloxanthin more than Staphylococcus capitis and non pigmented strain at different concentrations of $\mathrm{H}_{2} \mathrm{O}_{2}$. The viability of these strains had also been investigated in these figures after incubation with different concentrations of $\mathrm{H}_{2} \mathrm{O}_{2}$ in both dark and light conditions. This indicates the survival ability of Staphylococcus aureus producing staphyloxanthin in dark was better than light culturing condition due to the oxidation of staphyloxanthin, and thus this strain shows better survival ability than the other strains Staphylococcus capitis and non-pigmented strain of Staphylococcus aureus which is more susceptible to killing by hydrogen peroxide. These results had been accepted with other researches such as (Liu et al., 2008) that indicates the role of golden carotenoid pigment of Staphylococcus aureus, staphyloxanthin to promotes resistance to reactive oxygen species and host neutrophil-based killing. The early enzymatic steps in staphyloxanthin production resemble those of cholesterol biosynthesis and blocking staphyloxanthin biosynthesis is therefore a potentially attractive therapeutic target. Mishra et al., 2011, on the other hand, elucidated that carotenoid pigment of Staphylococcus aureus provides integrity to its cell membrane (CM) and limit oxidative host defense mechanism. Membrane pigments have also been hypothesized to be a virulence factor in Staphylococcus aureus potentially by detoxifying reactive 
oxygen species produced by phagocytes, such antioxidant potential of carotenoid pigment may be related to their specific orientation, location, and organization within the membrane (Widonska et al., 2009).

Lennette et al., 1985; Clauditz et al., 2006 elucidated that over 90\% of Staphylococcus aureus strains isolated from human infections are pigmented staphyloxanthin producing STX as an tritrerpenoid membran -bound carotenoid which plays a role in the environmental fitness $S$. aureus loss of pigmentation translates to a significant decrease in Staphylococcus aureus virulence in murin skin abscess or systemic infection mode (Liu et al., 2009).

Some biochemical properties of extracted and partially purified pigments of Staphylococcus aureus and Staphylococcus capitis had been studied such as conductivity and UV-spectra. High conductivity for both pigments had been registered 469.25 for Staphylococcus aureus and 391.25 for Staphylococcus capitis. As well as a significant peak at (478 nm, $466 \mathrm{~nm})$ as shown in Fig $(6,7)$ had been determined respectively for both staphyloxanthin and carotenoid pigment. Other researchers also determined the absorption spectra of purified staphyloxanthin such as Pelz et al., 2005, that obtained a peak between 463-490 nm, while Liu et al ., 2005 revealed triple-peak spectral profile of carotenoid pigment at 440-462-461nm wave length Clauditz et al., 2006 also elucidated that the absorption maxima of purified staphyloxanthin show a significant peak at $478 \mathrm{~nm}$ and this absorption had been decreased with the oxidation of purified staphyloxanthin by hydroxyl radicals generated in a Fenton reaction Lan et al., 2010 also measured the extracted carotenoid pigment optical density at $465 \mathrm{~nm}$. Sahin 2011 indicated that the absorption spectra can accelerate the identification and characterization of extracted and partial purified pigments from $S$. aureus at $468 \mathrm{~nm}$ when used with other distinctive biochemical tests. Antibacterial activity against a limited number of bacterial species had been also done. The highest antibacterial activity recorded against Staphylococcus epidermidis, Acinetobacter baumanii and Proteus mirabilis while the lowest activity was shown against Shigella dysenteri and Psedomonas aeruginosa Table (1), but no antibacterial effect had been shown by partially purified carotenoid pigment.

The conclusion of this research indicated that staphylococcal pigments are very important virulence factor due to its ability to resist the reactive oxygen species but it also acts as an antioxidant factor better than antibacterial agent against other bacterial isolates.

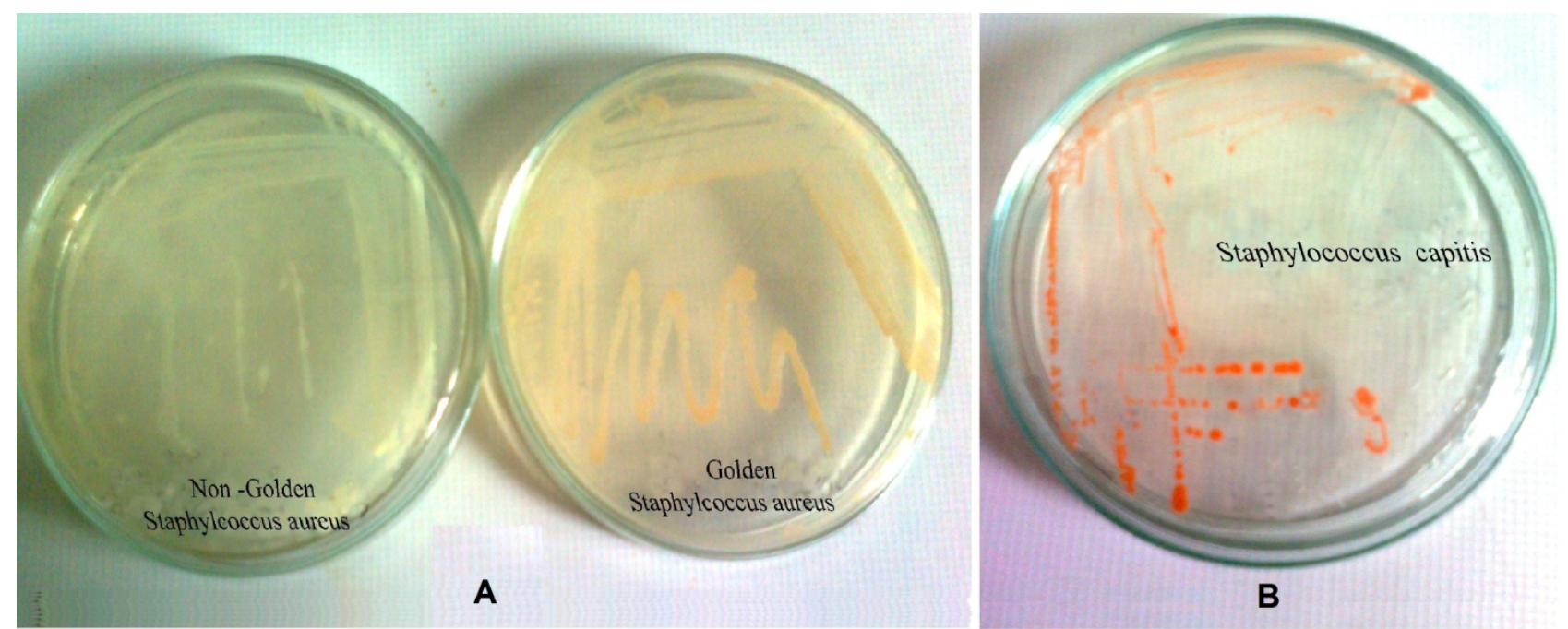

Fig. 2 : A: Staphylococcus aureus and B: Staphylococcus capitis on nutrient agar 


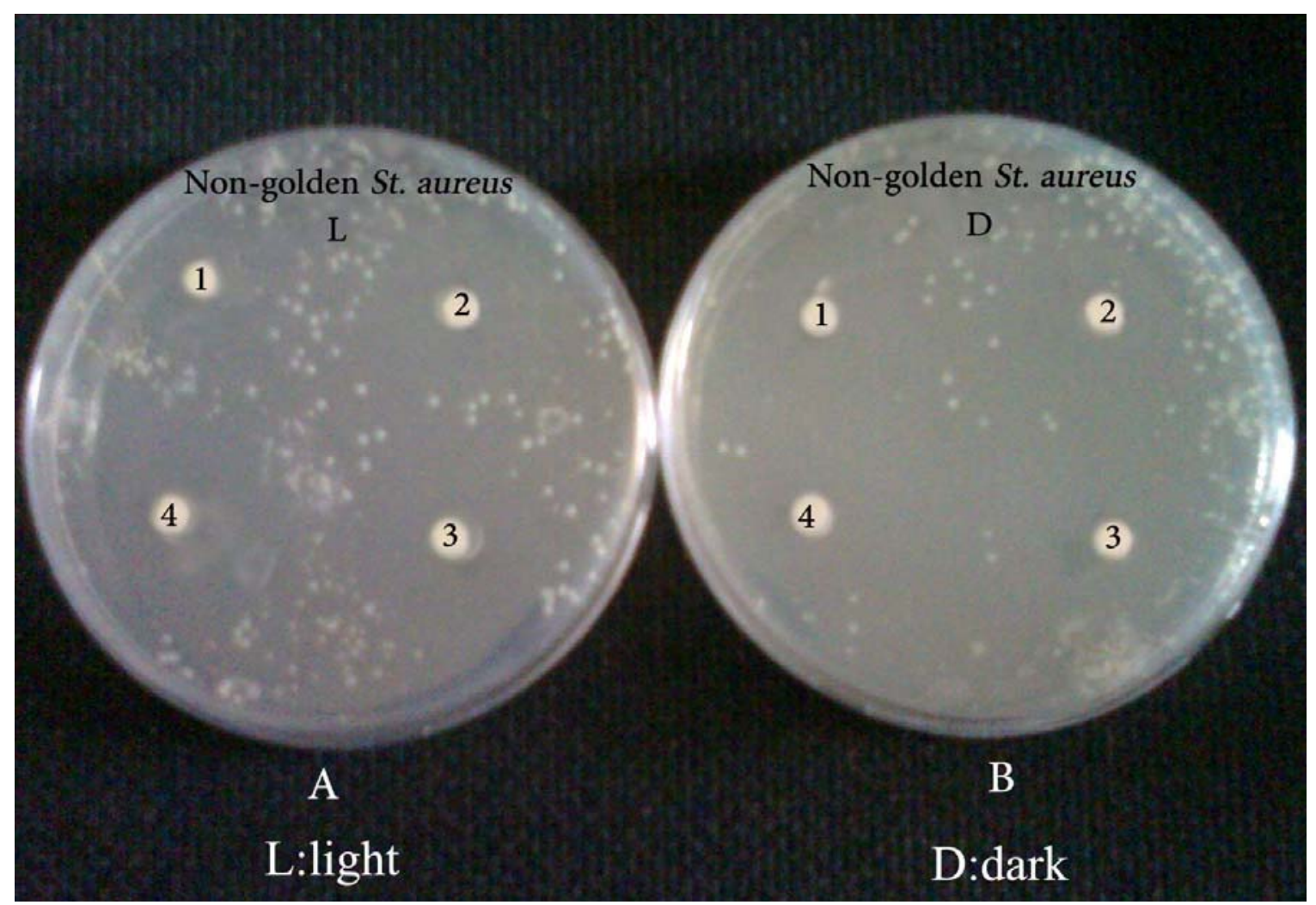

Fig. 3: Survival ability of Staphylococcus aureus non- producing staphyloxanthin cultured in light (A) and dark (B) condition with different concentration of $\mathrm{H}_{2} \mathrm{O}_{2}$ : $1=(0.6 \%), 2=(0.9 \%), 3=(1.2 \%), 4=(1.5 \%)$

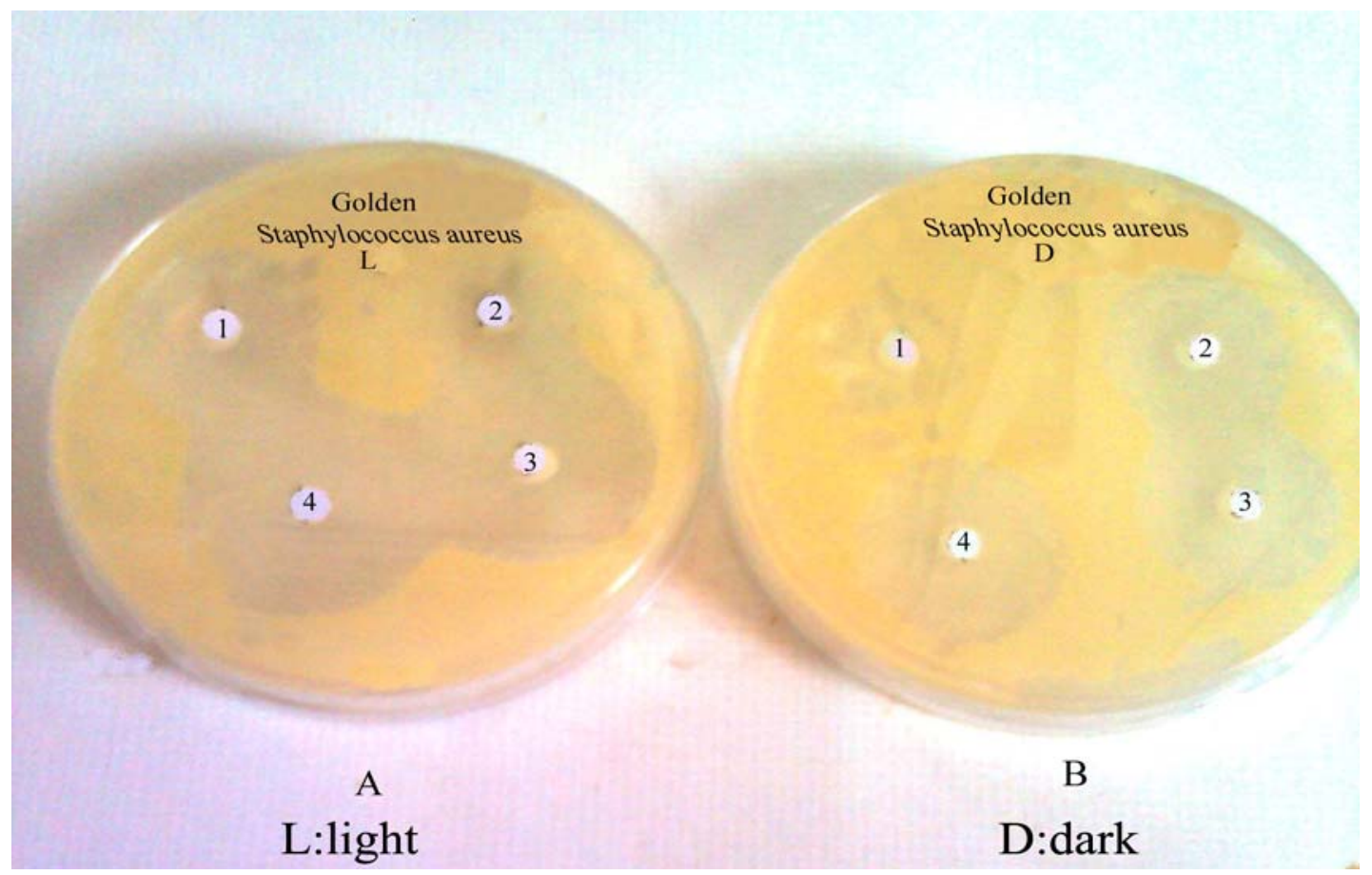

Fig. 4: Survival ability of Staphylococcus aureus producing staphyloxanthin cultured in light(A) and dark(B) condition with different concentration of $\mathrm{H}_{2} \mathrm{O}_{2}: 1=(0.6 \%), 2=$ $(0.9 \%), 3=(1.2 \%), 4=(1.5 \%)$ 


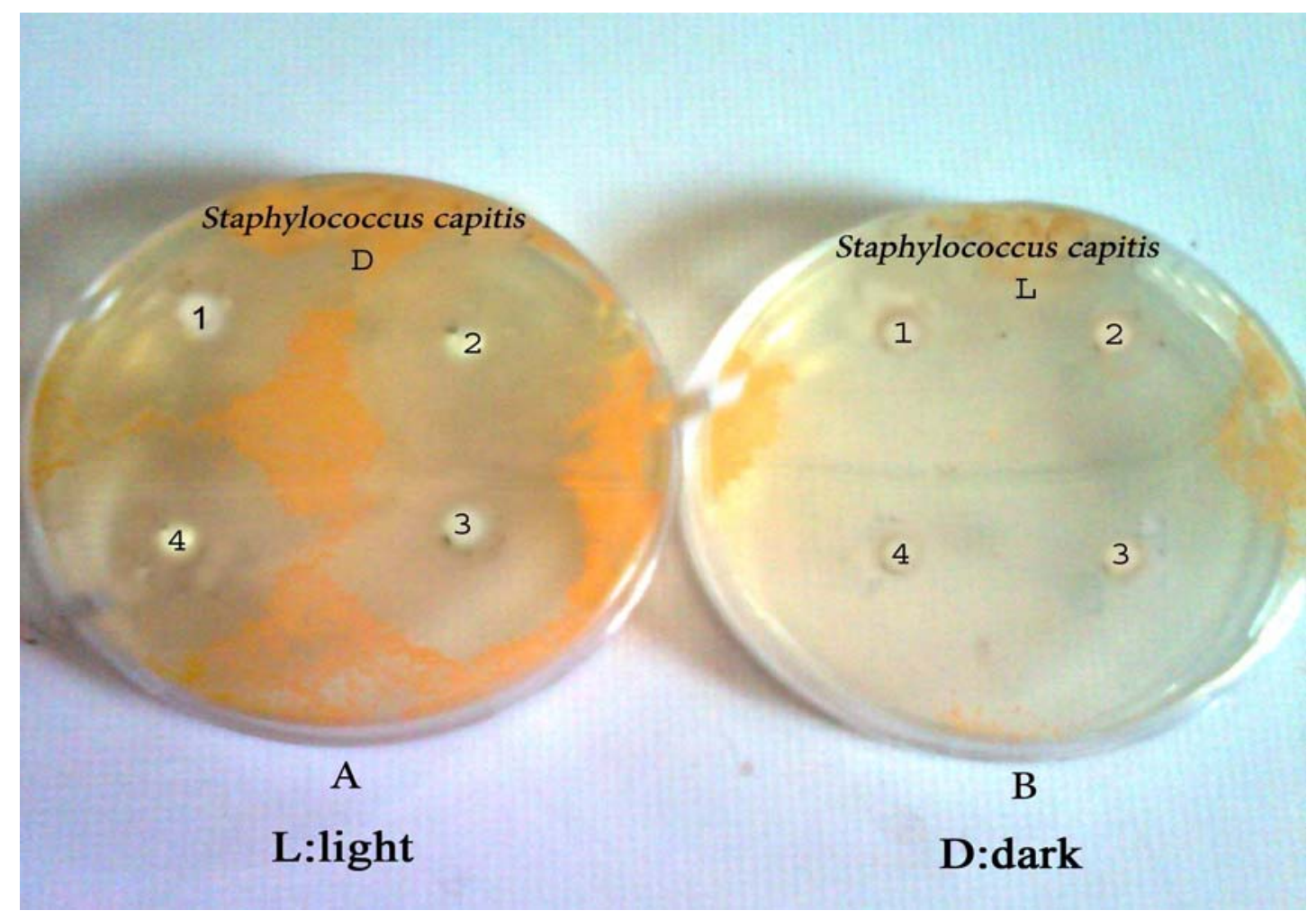

Fig. 5: Survival ability of Staphylococcus capitis producing pigment cultured in dark (A) and light (B) condition with different concentration of $\mathrm{H}_{2} \mathrm{O}_{2}: \quad 1=(0.6 \%), 2=(0.9 \%), 3=$ $(1.2 \%), 4=(1.5 \%)$

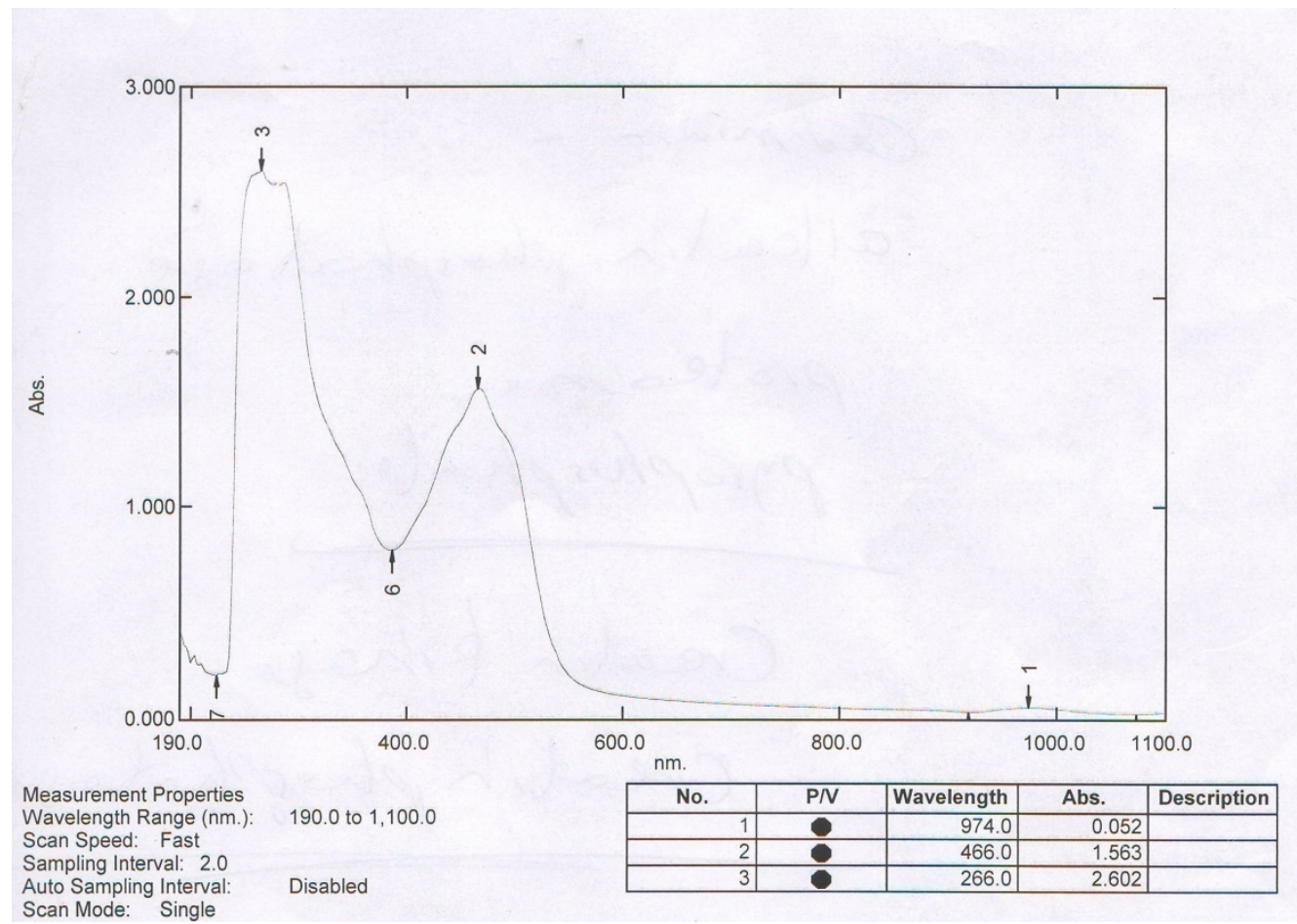

Fig. 6: UV-spectra of Extracted staphloxanthin from Staphylacoccus aureus. Peak 2 at 466 nm elucidate staphyloxanthin $\operatorname{spectrum(UV-1601)}$ 


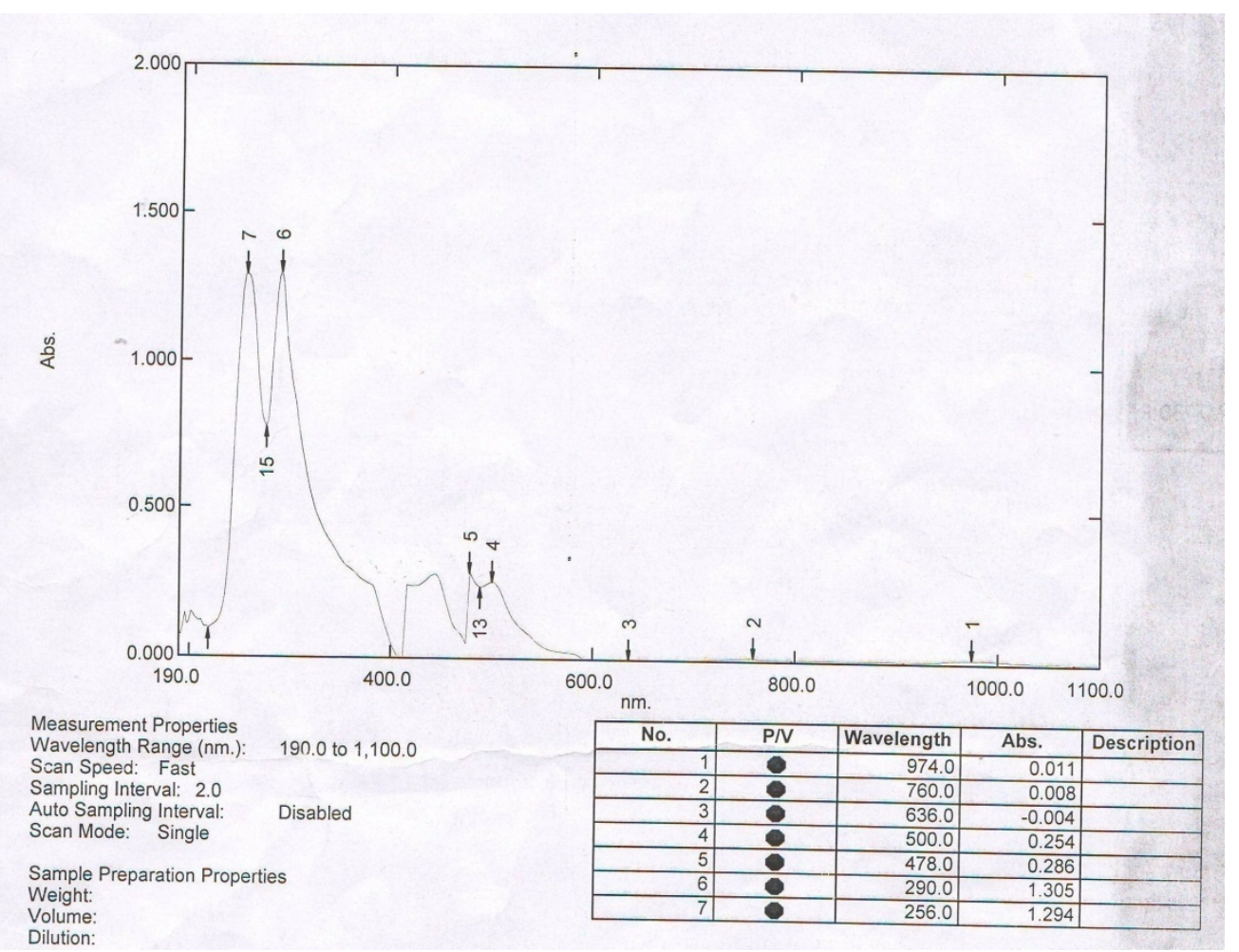

Fig. 7: UV-spectra of Extracted Carotenoied pigment from Staphylacoccus capitis Peak 5 at 478 nmelucidate the pigment spectrum(UV-1601)

Table 1:Antibacterial activity of staphyloxanthin against different bacterial species

\begin{tabular}{|l|c|c|}
\hline \multirow{2}{*}{\multicolumn{1}{c|}{ Bacterial species }} & \multicolumn{2}{|c|}{$\begin{array}{c}\text { Antibacterial activity } \\
\text { (diameter of zone inhibition in mm.) }\end{array}$} \\
\cline { 2 - 3 } & $\begin{array}{c}\text { Staphyloxanthin } \\
\text { Con. disc } \\
\mathbf{( 4 0 0} \mathbf{~ m g / m l )}\end{array}$ & $\begin{array}{c}\text { Imipemen } \\
\mathbf{( 1 0 ~ m c g )}\end{array}$ \\
\hline Acinetobacter baumanii & 12 & 37 \\
\hline Escherichia coli & 9 & 24 \\
\hline Proteus mirabilis & 12 & 24 \\
\hline klebsiella penumoniae & 10 & 23 \\
\hline Shigella dysenteri & 7 & 23 \\
\hline Salmonella enteritis & 8 & 23 \\
\hline Psedomonas aeruginosa & 7 & 33 \\
\hline Bacillus subtilis & 8 & 23 \\
\hline Staphyloccus epidermidis & 13 & 30 \\
\hline Acinetobacter baumanii & 12 & 37 \\
\hline
\end{tabular}

\section{REFERENCES}

Clauditz, A.; Resch, A.; Wieland, K.P.; Peschel, A.; Götz. (2006). Staphyloxanthin plays a role in fitness of Staphylococcus aureus and its ability to cope with oxidative stress. Infect. Immun. 74, 4950-4953.

Chung, P.Y.; Navaratnam, P.; Chung, L.Y. (2011). Synergistic antimicrobial activity between pentacyclic triterperioids and antibiotics against Staphylococcus aureus strains. Annals Clin. Microbi. and Antimicrobial. 5(10), 25-28. 
El-Agamey, A. (2004). Carotenoid radical chemistry and antioxidant/ pro- oxidant properties. Arch Biochem Biophys. 430, 37-48.

Fang, F.C. (2004). Antimicrobial reactive oxygen and nitrogen species: concepts and controversies. Nat Rev Microbiol. 2, 820-832.

Lan, L.; Cheng, A.; Dunman, P.M.; Missiakas, D.; He, C. (2010). Golden pigment roduction and virulence gene expression are affected by metabolism in Staphylococcus aureus. American Society for Mirobiology. 192(12), 3068- 3077.

Lennette, E.H.; Balows, A.; Hausler, W.J.; Shadomy, H.J. (1985). Manual of American Society for Microbiology clinical microbiology, 4th ed. Washington, DC, p. 146.

Lui, C.; Lui, G.Y.; Song, Y.; Yin, F.; Hensier, M.E.; Jeng, W.; Nizet, V.; Wang, A.H.J.; oldfield, E. (2008). Acholesterol biosynthesis inhibitor blocks Staphylococcus aureus virulence. Science. 319(5868), 1391-1394.

Liu, G. Y.; Essex, A.; Buchanan, J.T.; Datta, V.; Hoffman, H.M.; Bastian, J.F.; Fierer, J.; Nizet, V. (2005). Staphylococcus aureus golden impairs neutrophil killing and promotes virulence through its antioxidant activity. JEM. 202(2), 209-215.

Mishra, N.N.; Liu, G.; Yeamam, M.R.; Neast, C.C.; Proctor, R.A.; Mckinnella, J.; Bayer, S.A. (2011). Carotenoid-alteration of cell membrane fluidity impacts Staphylococcus aureus susceptibility to host defense peptides. American Soci. for Microbi. 55(2), 531-563.

Plez, A.; Wieland, K.P.; Putzbach, K.P.; Hentschel, P.; Albert, K.; Cötz, F. (2005). Structure and biosynthesis of staphyloxanthin from Staphylococcus aureus. The J. Biological Chem. 280, 32493-32498.

Ryan, K.J.; Ray, C.G (2004). Sherris Medical Microbiology (4th ed.). McGraw Hill.

Sahin, N. (2011). Significance of absorption spectra for chemotaxonomic characterization of pigmented bacteria. Turkey J. Bio. 35, 167-175.

Schmited, K.; Connor, A.; Britton, G. (1994). Analysis of pigments carotenoids and related polyenes. In Goodfellow M,O Donnel, AG. Eds. Chemical methods in prokaryotic systematic. Johan Willy and Sons. Ltd, 403-461.

Widomska, J.A.; Gugala, K.; Latowski, D.; Gruszecki, W.L.; Strzalka, K. (2009). Calorimetric studies of the effect of cis-carotenoids on the thermo tropic phase behavior of phosphatidylcholine bilayers. Biophys. Chem. 140, 108- 114. 